\title{
Analisis Penerimaan Sistem Informasi Akademik Dengan Menggunakan UTAUT 2 (Studi Kasus: Akademi Keperawatan Pembina Palembang)
}

\author{
Siska Anggraini', M. Haviz Irfani ${ }^{2}$, Sri Rahayu ${ }^{3}$ \\ Siskaaanggrainii29@gmail.com ${ }^{1}$, haviz.irfani@gmail.com ${ }^{2}$, srirahayu@ radenfatah.ac.id ${ }^{3}$ \\ ${ }^{1}$ Sistem Informasi, Fakultas Sains dan Teknologi, UIN Raden Fatah Palembang \\ ${ }^{2}$ Sistem Informasi, Fakultas Sains dan Teknologi, UIN Raden Fatah Palembang \\ ${ }^{3}$ Sistem Informasi, Fakultas Sains dan Teknologi, UIN Raden Fatah Palembang
}

Diterima: 15 April 2020 | Direvisi: 16 Mei 2020 | Disetujui: 18 Mei 2020

(c) 2020 Program Studi Sistem Informasi Fakultas Sains dan Teknologi,

Universitas Islam Negeri Raden Fatah Palembang, Indonesia

\begin{abstract}
Abstrak: Penerimaan terhadap sistem teknologi informasi penting untuk dilakukan karena dapat menjadi indikator bahwa sistem akan diterima dan diterapkan oleh pengguna untuk mendukung proses perkuliahan di Akademi Keperawatan Pembina Palembang. Tujuan dari penelitian ini adalah untuk mengetahui bagaimana pengaruh variabel model Unified Theory of Acceptance and Use of Technology (UTAUT) 2 terhadap penerimaan sistem informasi akademik dan seberapa besar tingkat penerimaan sistem informasi akademik menggunakan model UTAUT 2. Untuk mengetahui penerimaan sistem informasi peneliti menggunakan semua variabel utama dan variabel moderasi umur, jenis kelamin, pengalaman. Data penelitian ini menggunakan 135 responden yaitu 113 sampel mahasiswa dan 22 sampel dosen melalui penyebaran kuesioner. Analisis data yang digunakan yaitu menggunakan metode Structural Equation Modeling (SEM) dengan menggunakan tool Lisrel versi 8.70. Analisis SEM memiliki tahapan yaitu: (1) konseptualisasi model (2) membentuk path diagram (3) identifikasi model (4) estimasi model (5) penilaian model fit (6) menginterpretasikan hasil. Hasil penelitian menunjukan bahwa variabel espektasi kinerja berpengaruh sebesar (16.46), espektasi usaha berpengaruh sebesar (16.54), pengaruh sosial berpengaruh sebesar (14.85), motivasi hedonis berpengaruh sebesar (6.18), nilai harga berpengaruh sebesar (16.59), kebiasaan berpengaruh sebesar (15.94) terhadap niat perilaku. Variabel kondisi fasilitas berpengaruh sebesar (2.22) terhadap perilaku menggunakan. Variabel UTAUT 2 mampu mempengaruhi penerimaan sistem sebesar 9,4\%.
\end{abstract}

Kata Kunci: Sistem informasi akademik, UTAUT 2, Structural Equation Modeling

\begin{abstract}
Acceptance of information technology systems is important to do because it can be an indicator that the system will be accepted and implemented by users to support the lecture process at the Palembang Nursing Academy of Nursing. The purpose of this study was to determine how the influence of the Unified Theory of Acceptance and Use of Technology (UTAUT) 2 model variable on the acceptance of academic information systems and how much the level of acceptance of academic information systems using the UTAUT 2 model. To determine the acceptance of information systems researchers used all the main variables and moderating variables age, sex, experience. The data of this study used 135 respondents, namely 113 student samples and 22 lecturer samples through questionnaires. Analysis of the data used is using the Structural Equation Modeling (SEM) method using the Lisrel tool version 8.70. SEM analysis has stages: (1) conceptualization of the model (2) forming a path diagram (3) identification of the model (4) estimation of the model (5) assessment of the fit model (6) interpreting the results. The results showed that the variable performance expectations had an effect of (16.46), business expectations had an effect of (16.54), social influence had an effect of (14.85), hedonic motivation had an effect of (6.18), the price value had an effect of (16.59), habits had an effect of (15.94) ) towards behavioral intentions. The variable condition of the facility has an effect of (2.22) on the behavior of using. UTAUT 2 variable is able to influence system acceptance by $9.4 \%$.
\end{abstract}


Keywords: Academic information system, UTAUT2, Structural Equation Modeling

\section{PENDAHULUAN}

Saat ini banyak organisasi yang menerapkan sistem teknologi informasi modern dan canggih dengan biaya tinggi akan tetapi permasalahan yang timbul adalah masih di pengaruhi rendahnya penggunaan dan penerimaan sistem informasi secara berkesinambungan. Rendahnya penggunaan sistem informasi diidentifikasi menjadi penyebab utama productivity paradox di pengaruhi yaitu mahalnya investasi di bidang sistem tetapi return yang dihasilkan rendah (Venkatesh dan Davis, 2000).

Sehingga untuk memantanance sistem yang telah terapkan dan juga dapat menekan budget yang telah di keluarkan untuk penerapan sistem itu sendiri sangat penting untuk menganalisis penerimaan sistem informasi akademik di Akademi Keperawatan Pembina Palembang karena belum pernah melakukan evaluasi untuk mengetahui sejauh mana penerimaan sistem informasi Akademik Keperawatan Pembina Palembang. Serta mengevaluasi sistem informasi akademik ini sangat perlu dilakukan untuk mengetahui apakah sistem informasi yang diterapkan sudah sesuai dengan yang diharapkan oleh user dan apakah informasi yang dihasilkan oleh sistem informasi akademik sudah sesuai dengan yang dibutuhkan user serta Akademi Keperawatan Pembina Palembang mengetahui apakah tujuan dari digunakannya sistem informasi akademik sudah tercapai atau belum. Selain itu juga, kekurangan-kekurangan yang ada pada sistem informasi akademik tidak dapat di evaluasi dan hambatan tidak bisa diidentifikasi sehingga kebutuhan yang diharapkan tidak dapat diusulkan perbaikannya

Secara teoritis dan praktis model UTAUT banyak digunakan untuk mengukur penerimaan penerapan sistem informasi akademik berdasarkan keinginan pengguna dalam menggunakan sistem informasi tersebut (Hamrul, dkk). Kemudian pada tahun 2012 (Venkatesh, et al) mengemukakan pengembangan UTAUT menjadi UTAUT2 dengan menambahkan tiga variabel utama yaitu hedonic motivation (motivasi hedonis), price value (nilai harga) dan habit (kebiasaan) dengan fokus pada tiga variabel moderator yaitu age (usia), gender (jenis kelamin) dan experience (pengalaman) (Venkatesh et al, 2012). Penelitian ini menggunakan UTAUT 2 karena termasuk model adopsi atau perilaku dan penerimaan teknologi informasi yang terbaru yang telah teruji dan tervalidasi dalam konteks konsumen (Nugroho, dkk). Di harapkan dengan adanya penambahan model di UTAUT 2 dapat mengukur penerimaan sistem informasi akademik.

\section{METODOLOGI PENELITIAN}

Metode penelitian dalam penelitian ini menggunakan pendekatan kuantitatif untuk mendapatkan pengumpulan data kuesioner dengan tujuan dan kegunaan tertentu. Dari jenis pengambilan data pendekatan kuantitatif karena penelitian ini akan memberikan beberapa pertanyaan kepada responden yaitu mahasiswa dan dosen. Pada penelitian ini menggunakan analisis data dengan Metode SEM software Lisrel v.8.70.

\subsection{Model UTAUT 2}

Model UTAUT adalah model gabungan yang disebut dengan nama teori gabungan penerimaan dan penggunaan teknologi UTAUT yang dikembangkan oleh (Venkatesh, et al. 2003), kemudian menggunakan teori-teori yang sudah ada sebelumnya untuk mengembangkan sebuah model gabungan baru yang terintegrasi. UTAUT menempatkan niat perilaku (behavioral intention) dan penggunaan sebagai variabel dependen sedangkan empat variabel utama dalam UTAUT adalah espektasi kinerja, espektasi usaha, pengaruh sosial dan kondisi fasilitas sebagai variabel independen. UTAUT memiliki empat variabel moderasi yaitu jenis kelamin, usia, pengalalaman dan 
kesukarelaan. Pada tahun 2012 (Venkatesh, et al.) mengemukakan pengembangan UTAUT menjadi UTAUT 2 dengan menambahkan tiga variabel utama yaitu motivasi hedonis, nilai harga dan kebiasaan. Model UTAUT 2 dapat dilihat pada Gambar 1.

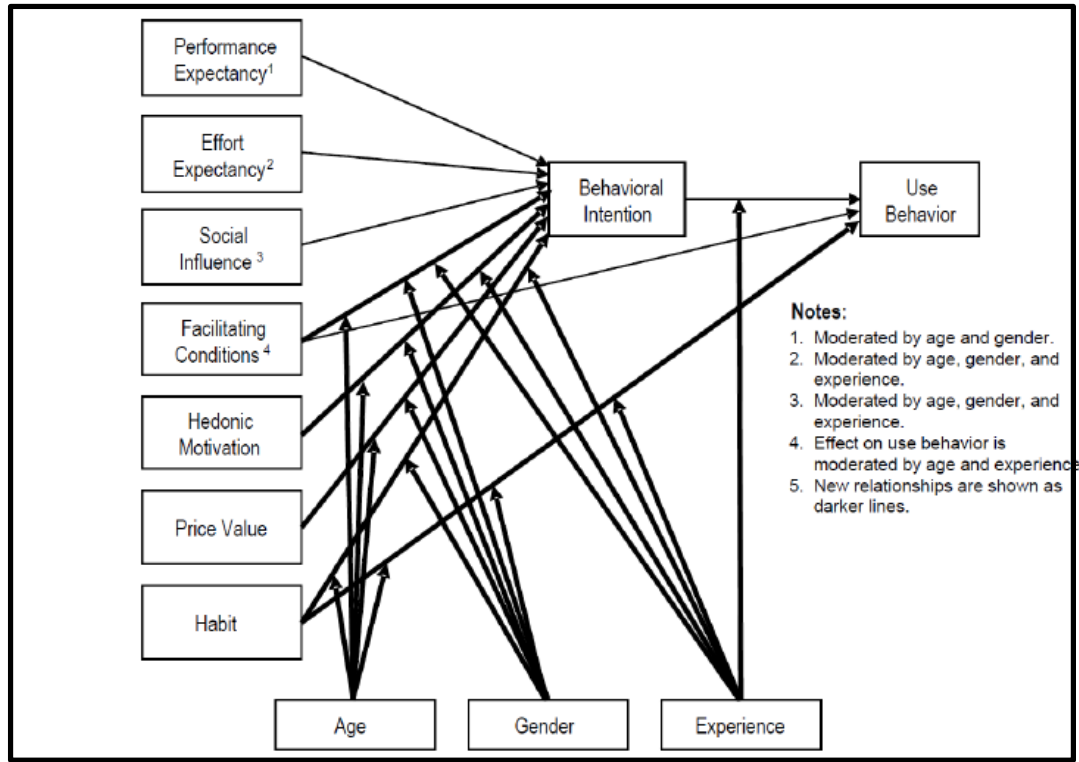

Gambar 1 Model UTAUT 2

(Sumber: Venkatesh. et al, 2012)

\subsection{Model Persamaan Struktural (Structural Equation Modeling)}

Merupakan generasi kedua teknik analisis multivariate (Bagozzi dan Fornell, 1982) yang akan digunakan untuk menguji hubungan antar variabel untuk mengambarkan menyeluruh mengenai keseluruhan model. Komponen-komponen Model SEM variabel laten, variabel teramati, model struktural, model pengukuran.

\subsection{SEM dengan hubungan Moderasi (Moderated Structural Equation Modeling)}

Menurut (Ghozali, 2014), Moderated Structural Equation Modeling ialah pengaruh suatu variabel laten yang berpengaruh terhadap hubungan antara variabel laten independen dan variabel laten dependen. Dalam Structural Equation Modeling (SEM) terdapat beberapa metode yang dapat menilai pengaruh moderating. Salah satu metode termudah dan dapat mengestimasi pengaruh pada Structural Equation Modeling (SEM) yang kompleks adalah metode Ping (1995).

$$
\left\{y=a+b_{1} x_{1}+b_{2} z_{2}+b_{3} x_{1} z_{2}\right\}
$$

\section{Gambar 2 Rumus Moderated Structural Equation Modeling}

(Sumber: Imam Ghozali, 2014)

\subsection{Populasi dan Sampel}

\subsubsection{Populasi}

Populasi yang digunakan adalah seluruh yang mengunakan sistem informasi akademik yaitu mahasiswa dan dosen. Jumlah mahasiswa sebanyak 172 populasi dan dosen 33 populasi. Total keseluruhan adalah 205 populasi. 


\subsubsection{Sampel}

Peneliti menggunakan rumus slovin dengan tingkat signifikansi 5\%. Dari total populasi sebanyak 205 maka didapatkan jumlah sampel sebanyak 135 sampel. Berikut perhitungan dengan menggunakan rumus slovin.

Diketahui:

$\mathrm{N}=205$

$\mathrm{e}=5 \%(0,05)$

$\mathrm{n}=\frac{\mathrm{N}}{1+\mathrm{Ne}^{2}}=\frac{205}{1+205(0,05)^{2}}=\frac{205}{1+205(0,0025)}=\frac{205}{1+0,5125}=\frac{205}{1,5125}=135$ Sampel

\subsection{Tahapan Penelitian}

Tahapan penelitian menggambarkan proses penelitian yang digambarkan secara keseluruhan, dengan tujuan agar sebuah penelitian lebih terarah dan dapat dengan mudah dilaksanakan sesuai dengan tahapannya. Penelitian ini menggunakan tahapan kuantitatif dan tahapan SEM, dapat dilihat pada Gambar 3.

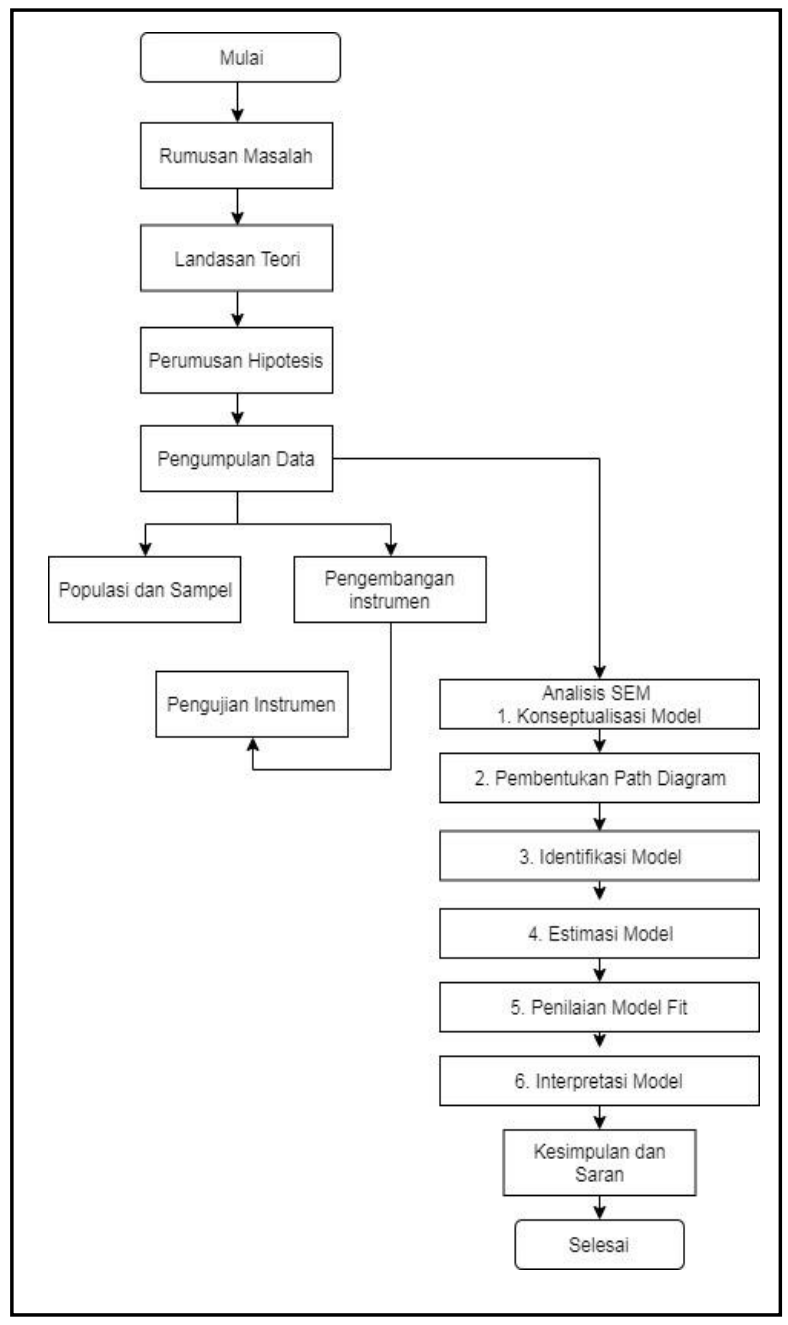

Gambar 3 Tahapan Penelitian 


\section{HASIL DAN PEMBAHASAN}

\subsection{Gambaran Umum Responden}

1. Karakteristik berdasarkan usia

\section{Responden Berdasarkan Usia}

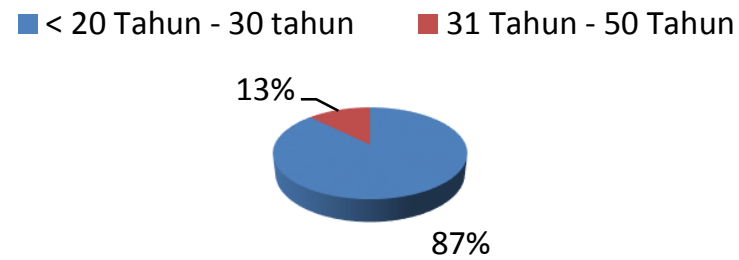

Gambar 4 Diagram pie berdasarkan usia

(Sumber: Hasil Pengolahan Data)

Berdasarkan Gambar 4, bahwa 87\% responden berusia < 20 tahun-30 tahun, 13\% responden berusia 31 tahun-50 tahun. Dapat disimpulkan bahwa pengguna sistem informasi akademik didominasi oleh orang-orang yang berusia relatif muda $(<20$ tahun-30 tahun) sebanyak 118 orang atau $87 \%$ dari jumlah keseluruhan.

2. Karakteristik berdasarkan jenis kelamin

Responden Berdasarkan Jenis Kelamin

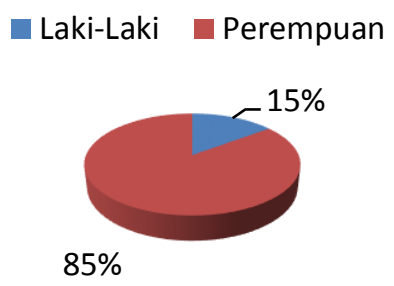

\section{Gambar 5 Diagram Pie Berdasarkan Jenis Kelamin}

(Sumber: Hasil Pengolahan Data)

Berdasarkan Gambar 5, menunjukan bahwa 15\% responden berjenis kelamin laki-laki dan $85 \%$ responden berjenis kelamin perempuan. Dapat disimpulkan bahwa mayoritas responden berjenis kelamin perempuan sebanyak 115 orang atau $85 \%$ dari jumlah keseluruhan responden.

3. Karakteristik berdasarkan pengalaman

\section{Responden Berdasarkan Pengalaman}

$$
\text { - Sudah menggunakan Belum Menggunakan }
$$

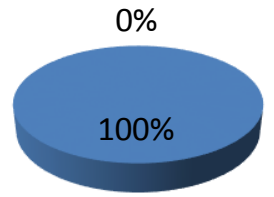

Gambar 6 Diagram pie berdasarkan pengalaman

(Sumber: Hasil Pengolahan Data) 
Berdasarkan Gambar 6 menunjukkan bahwa 100\% responden sudah menggunakan sistem informasi akademik. Dapat disimpulkan bahwa semua responden sudah berpengalaman menggunakan sistem informasi akademik, dikarenakan penggunanya adalah mahasiswa aktif dan dosen pengampuh mata kuliah yang menggunakan sistem informasi akademik dalam menunjang proses perkuliahan.

\subsection{Uji Normalitas}

Normalitas univariat dan normalitas multivariat data yang digunakan dalam analisis ini dapat diuji normalitasnya dapat dilihat pada Gambar 7.

\begin{tabular}{|c|c|c|c|c|c|c|}
\hline \multicolumn{7}{|c|}{ Test of Univariate Normality for Continuous Variables } \\
\hline Variable & z-Score & P-Value & z-Score & P-Value & Chi-Square & P-Value \\
\hline EK1 & -1.524 & 0.127 & -0.457 & 0.648 & 2.533 & 0.282 \\
\hline EK2 & -1.381 & 0.167 & -0.027 & 0.979 & 1.909 & 0.385 \\
\hline EK3 & -1.447 & 0.148 & -0.620 & 0.535 & 2.477 & 0.290 \\
\hline ER4 & -1.113 & 0.266 & -0.056 & 0.955 & 1.242 & 0.537 \\
\hline EU1 & -1.165 & 0.244 & -0.539 & 0.590 & 1.649 & 0.439 \\
\hline EU2 & -1.224 & 0.221 & -0.301 & 0.763 & $\begin{array}{l}1.079 \\
1.588\end{array}$ & 0.452 \\
\hline EU3 & -1.014 & 0.310 & -0.370 & 0.711 & 1.166 & 0.558 \\
\hline PS1 & -1.242 & 0.214 & 0.232 & 0.817 & 1.597 & 0.450 \\
\hline PS2 & -1.284 & 0.199 & -0.477 & 0.633 & 1.877 & 0.391 \\
\hline PS3 & -1.147 & 0.251 & 0.223 & 0.824 & 1.366 & 0.505 \\
\hline $\mathrm{KF} 1$ & -1.263 & 0.207 & 0.146 & 0.884 & 1.617 & 0.446 \\
\hline KF2 & -1.141 & 0.254 & -0.035 & 0.972 & 1.303 & 0.521 \\
\hline $\mathrm{KF} 3$ & -1.317 & 0.188 & -0.008 & 0.993 & 1.734 & 0.420 \\
\hline MH1 & -1.020 & 0.308 & 0.362 & 0.717 & $\begin{array}{l}1.172 \\
1.172\end{array}$ & 0.557 \\
\hline MH2 & -1.154 & 0.249 & 0.162 & 0.871 & 1.358 & 0.507 \\
\hline MH3 & -1.190 & 0.234 & 0.071 & 0.943 & 1.422 & 0.491 \\
\hline H1 & -1.458 & 0.145 & -1.179 & 0.238 & 3.516 & 0.172 \\
\hline H2 & -1.186 & 0.236 & 0.284 & 0.776 & 1.487 & 0.475 \\
\hline $\mathrm{K} 1$ & -1.206 & 0.228 & 0.194 & 0.846 & 1.492 & 0.474 \\
\hline K2 & -1.118 & 0.264 & 0.746 & 0.455 & 1.806 & 0.405 \\
\hline K3 & -1.336 & 0.182 & -0.137 & 0.891 & 1.804 & 0.406 \\
\hline N1 & -1.464 & 0.143 & -0.384 & 0.701 & 2.291 & 0.318 \\
\hline N2 & -1.154 & 0.249 & 0.535 & 0.593 & 1.618 & 0.445 \\
\hline PP1 & -0.399 & 0.690 & -1.012 & 0.312 & 1.183 & 0.554 \\
\hline PP2 & -1.444 & 0.149 & -0.697 & 0.486 & 2.570 & 0.277 \\
\hline
\end{tabular}

Gambar 7 Uji Normalitas

(Sumber: Hasil Pengolahan Data)

Dalam uji normalitas di atas, data dapat dikatakan berdistribusi normal apabila $P$-Value Skewness dan Kurtosis $\geq 0,05$. Normalitas menunjukan hasil pengujian normalitas untuk setiap variabel. Berdasarkan hasil output diatas dapat dilihat bahwa semua variabel memenuhi normalitas.

\subsection{Uji Validitas}

Hasil uji validitas dalam model SEM pada software Lisrel 8.70 pada tahap Confirmatory Factor Analysis (CFA) variabel-variabel teramati atau indikator pada tiap variabel laten harus memenuhi persyaratan validitas dan reliabilitas terlebih dahulu. Output yang akan ditampilkan menjadi 2 variabel yaitu variabel eksogen dan variabel endogen dimana nantinya yang terdapat dalam path diagram akan menginformasikan tentang standardized solution yang menunjukan loading factor yang akan digunakan untuk mengukur validitas pada software lisrel 8.7. Dapat dilihat pada Gambar 8 ialah variabel eksogen. 


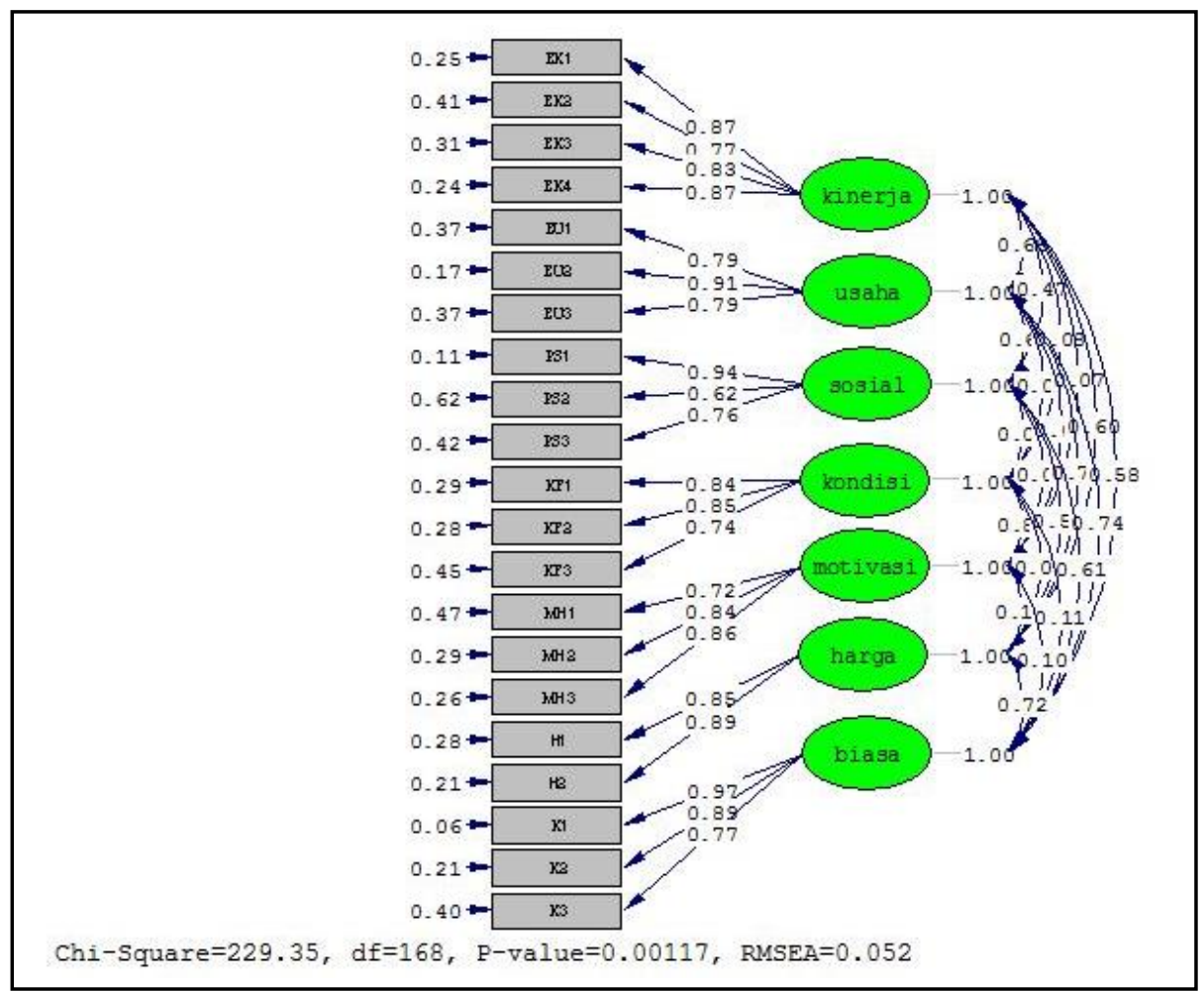

Gambar 8 Uji Validitas Variabel Eksogen

(Sumber: Hasil Pengolahan Data)

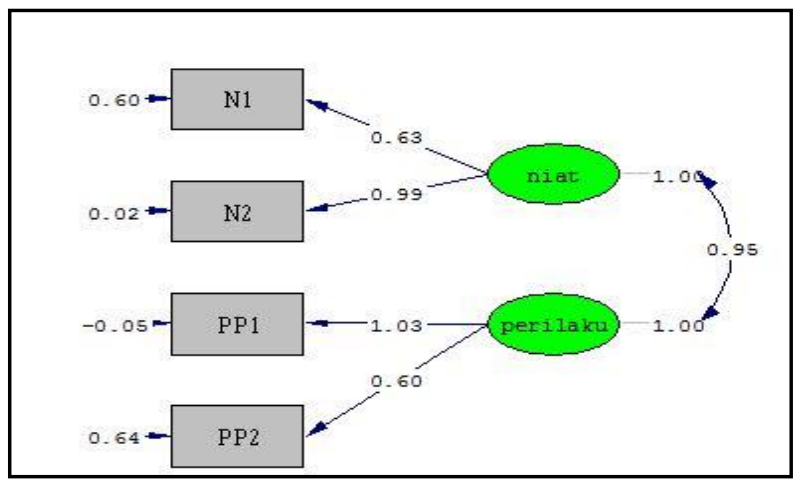

\section{Gambar 9 Uji Validitas Variabel Endogen}

(Sumber: Hasil Pengolahan Data)

Berdasarkan pada Gambar 8 dan Gambar 9 disimpulkan bahwa indikator-indikator yang membentuk variabel laten semuanya valid / signifikan.

\subsection{Uji Reliabilitas}

Variabel dikatakan reliabel jika $\mathrm{CR} \geq 0.70$ dan $\mathrm{VE} \geq 0.50$. Tabel 1 menunjukan hasil evaluasi reliabilitas masing-masing variabel laten ataupun indikator di bawah ini:

Tabel 1 Hasil Perhitungan Uji Reliabilitas

\begin{tabular}{clcccc}
\hline No. & \multicolumn{2}{c}{ Nama Variabel } & $\begin{array}{c}\text { Composite } \\
\text { Reliability (CR ) }\end{array}$ & $\begin{array}{c}\text { Average Variances } \\
\text { Extracted ( AVE ) }\end{array}$ & Keterangan \\
\hline 1 & $\begin{array}{l}\text { Espektasi } \\
\text { (Performance } \\
\text { Expectancy) }\end{array}$ & Kinerja & 0.90 & 0.7 & Reliabel \\
& & & & \\
\end{tabular}




\begin{tabular}{clccc}
\hline \hline No. & \multicolumn{1}{c}{ Nama Variabel } & $\begin{array}{c}\text { Composite } \\
\text { Reliability ( CR ) }\end{array}$ & $\begin{array}{c}\text { Average Variances } \\
\text { Extracted ( AVE ) }\end{array}$ & Keterangan \\
\hline 2 & $\begin{array}{l}\text { Espektasi Usaha (Effort } \\
\text { Expectancy), }\end{array}$ & 0.86 & 0.69 & Reliabel \\
\hline 3 & $\begin{array}{l}\text { Pengaruh Sosial (Social } \\
\text { Influence) }\end{array}$ & 0.81 & 0.60 & Reliabel \\
\hline 4 & $\begin{array}{l}\text { Kondisi fasilitas } \\
\text { (facilitating conditions) }\end{array}$ & 0.85 & 0.65 & Reliabel \\
\hline 5 & $\begin{array}{l}\text { Motivasi hedonis } \\
\text { (hedonic motivation) }\end{array}$ & 0.84 & 0.65 & Reliabel \\
\hline 6 & $\begin{array}{l}\text { Nilai harga (price } \\
\text { value) }\end{array}$ & 0.86 & 0.77 & Reliabel \\
\hline 7 & $\begin{array}{l}\text { Kebiasaan (habit) } \\
\text { Niat Perilaku } \\
\text { (Behavioral Intentions) }\end{array}$ & 0.91 & 0.68 & 0.90 \\
\hline 9 & $\begin{array}{l}\text { Perilaku menggunakan } \\
\text { (Use Behavioral) }\end{array}$ & 0.94 & Reliabel \\
\hline
\end{tabular}

(Sumber: Hasil Pengolahan Data)

Berdasarkan Tabel 1, hasil perhitungan nilai Composite Reliability $(C R) \geq 0.70$. dan Average Variances Extracted $(A V E) \geq 0.50$. Dapat disimpulkan bahwa indikator-indikator variabel UTAUT 2 adalah reliabel.

\subsection{Uji kecocokan Keseluruhan Model}

Setelah signifikan pengujian validitas dan reliabilitas dengan model $C F A$, maka tahap selanjutnya adalah menganalisis kecocokan data dengan model secara keseluruhan atau dalam lisrel disebut Goodness of Fit (GOF). Pengujian ini akan mengevaluasi apakah model yang dihasilkan estimasi pengukuran CFA pada software lisrel, analisis kecocokan keseluruhan model dapat dilihat pada Tabel 2.

Tabel 2 Uji Kecocokan Keseluruhan Model

\begin{tabular}{ccccc}
\hline No & GOF & $\begin{array}{c}\text { Tingkat Kecocokan yang dapat } \\
\text { diterima (Cut off Value })\end{array}$ & $\begin{array}{c}\text { Hasil Estimasi } \\
(\text { Indeks model })\end{array}$ & Evaluasi \\
\hline 1 & Chi-square & Semakin kecil semakin baik & 341.96 & Baik \\
\hline 2 & Probability & $\geq 0,05$ & 0.002 & Marginal \\
\hline 3 & GFI & $\geq 0,90$ & 0.97 & Good fit \\
\hline 4 & AGFI & $\geq 0,90$ & 0.97 & Good fit \\
\hline 5 & RMSEA & $\leq 0.08$ & 0.055 & Good fit \\
\hline 6 & RMSR & $\leq 0.05$ & 0.036 & Good fit \\
\hline 7 & CFI & $\geq 0,90$ & 1.00 & Good fit
\end{tabular}

(Sumber: Hasil Pengolahan Data)

Berdasarkan Tabel 2, Goodness of Fit (Uji Kecocokan Keseluruhan Model) melihat nilai Chi-square test, RMSEA, CFI dan RMSR. Oleh karena itu, uji kecocokan menunjukan model fit maka dapat disimpulkan bahwa model yang digunakan dalam penelitian ini dapat dijadikan dasar analisis terhadap permasalahan penelitian ini dan pengujian hipotesis dapat dilanjutkan.

\subsection{Uji Kecocokan Model Structural}

Pengujian second confirmatory factor analysis (Second Order CFA) untuk menghasilkan statistik pengukuran struktural yang lebih tepat dan akurat dengan melihat

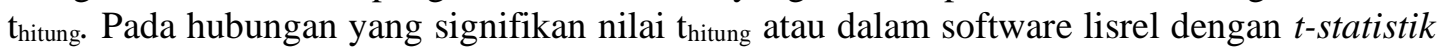


yang berwarna hitam pada path diagram dengan nilai $\geq 1,98$. Sedangkan hubungan yang tidak signifikan ditandai dengan $t$-value yang berwarna merah pada path diagram dengan nilai $\leq 1,98$.

\subsubsection{Interpretasi Model}

Interpretasi model ialah hasil perhitungan dari uji t-statistik yang dilakukan dengan menggunakan software lisrel versi 8.70. Berikut hasil uji t-statistik dapat dilihat pada Gambar 10.

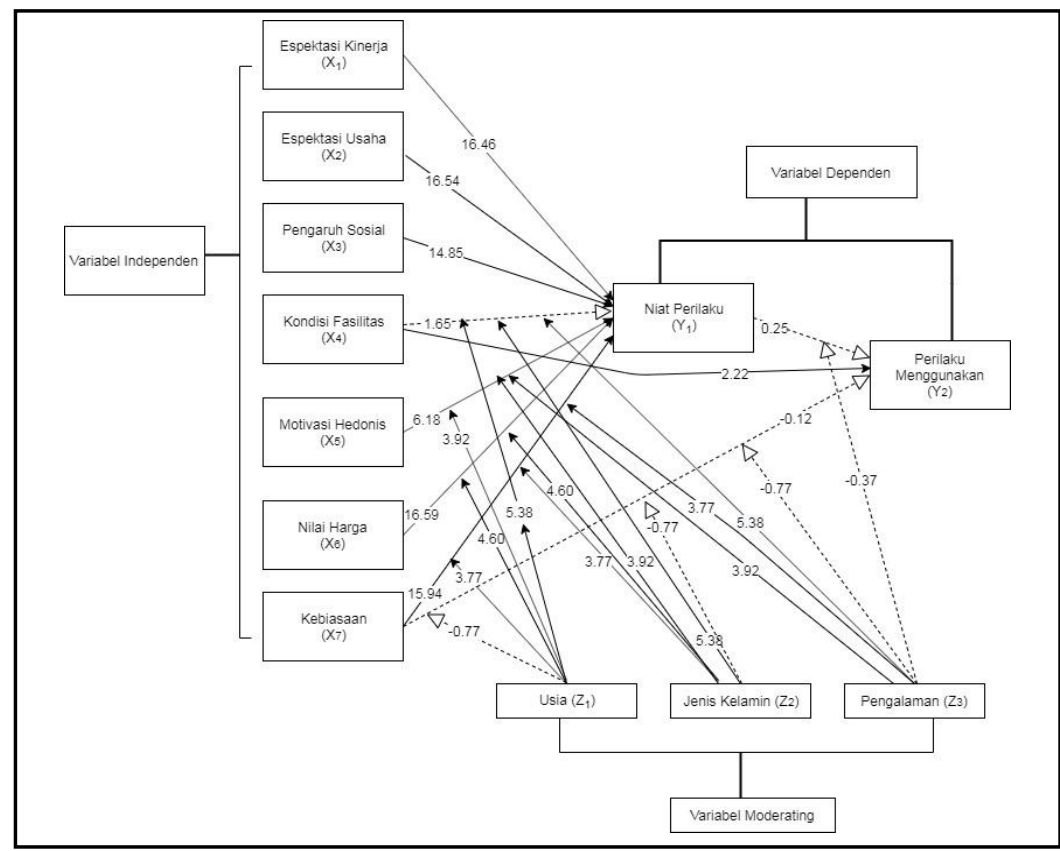

Gambar 10 Hasil Interpretasi Model UTAUT 2

(Sumber: Hasil Pengolahan Data)

\section{1) Interpretasi Espektasi kinerja $\left(\mathrm{X}_{1}\right)$ terhadap Niat perilaku $\left(\mathrm{Y}_{1}\right)$}

Berdasarkan hasil uji statistik bahwa hasil perhitungan pada penelitian ini menunjukan bahwa variabel espektasi kinerja memiliki nilai thitung sebesar 16.46 dan tingkat signifikan $\alpha=$ $5 \%$ adalah $\mathrm{t}_{\text {tabel }}=1.98$. Karena nilai $\mathrm{t}_{\text {hitung }}$ sebesar $16.46 \geq$ nilai $\mathrm{t}_{\text {tabel }}=1.98$, maka dapat disimpulkan bahwa pengaruh yang terjadi antara variabel espektasi kinerja terhadap niat perilaku signifikan secara statistik pada tingkat signifikansi 5\%.

\section{2) Interpretasi Espektasi usaha $\left(\mathbf{X}_{2}\right)$ terhadap Niat perilaku $\left(\mathbf{Y}_{1}\right)$}

Berdasarkan hasil uji statistik bahwa hasil perhitungan pada penelitian ini menunjukan bahwa variabel sespektasi usaha memiliki nilai thitung sebesar 16.54 dan tingkat signifikan $\alpha=$ $5 \%$ adalah $\mathrm{t}_{\text {tabel }}=1.98$. Karena nilai $\mathrm{t}_{\text {hitung }}$ sebesar $16.54 \geq$ nilai $\mathrm{t}_{\text {tabel }}=1.98$, maka dapat disimpulkan bahwa pengaruh yang terjadi antara variabel espektasi usaha terhadap niat perilaku signifikan secara statistik pada tingkat signifikansi 5\%.

\section{3) Interpretasi Pengaruh sosial $\left(\mathrm{X}_{3}\right)$ terhadap Niat perilaku $\left(\mathrm{Y}_{1}\right)$}

Berdasarkan hasil uji statistik bahwa hasil perhitungan pada penelitian ini menunjukan bahwa variabel pengaruh sosial memiliki nilai $t_{\text {hitung }}$ sebesar 14.85 dan tingkat signifikan $\alpha=$ $5 \%$ adalah $\mathrm{t}_{\text {tabel }}=1.98$. Karena nilai $\mathrm{t}_{\text {hitung }}$ sebesar $14.85 \geq$ nilai $\mathrm{t}_{\text {tabel }}=1.98$, maka dapat disimpulkan bahwa pengaruh yang terjadi antara variabel pengaruh sosial terhadap niat perilaku signifikan secara statistik pada tingkat signifikansi 5\%.

\section{4) Interpretasi Kondisi fasilitas $\left(\mathbf{X}_{4}\right)$ terhadap Niat perilaku $\left(\mathbf{Y}_{1}\right)$}

Berdasarkan hasil uji statistik bahwa hasil perhitungan pada penelitian ini menunjukan bahwa variabel kondisi fasilitas memiliki nilai $t_{\text {hitung }}$ sebesar 1.65 dan tingkat signifikan $\alpha=$ 
$5 \%$ adalah $\mathrm{t}_{\text {tabel }}=1.98$. Karena nilai $\mathrm{t}_{\text {hitung }}$ sebesar $1.65 \leq$ nilai $\mathrm{t}_{\text {tabel }}=1.98$, maka dapat disimpulkan bahwa pengaruh yang terjadi antara variabel kondisi fasilitas terhadap niat perilaku tidak signifikan secara statistik pada tingkat signifikansi 5\%.

Dari hasil moderasi usia, jenis kelamin, pengalaman didapatkan nilai dari variabel laten interaksi terhadap variabel kondisi fasilitas nilai thitung 5.38 lebih besar dari pada batas signifikan level 5\% yaitu $t_{\text {tabel }}$ 1.98. Hal ini menunjukan bahwa Ho ditolak. Dapat disimpulkan, keberadaan usia, jenis kelamin, pengalaman sebagai moderasi memperkuat hubungan antara pengaruh kondisi fasilitas terhadap niat perilaku.

\section{5) Interpretasi Motivasi hedonis ( $\left.\mathrm{X}_{5}\right)$ terhadap Niat perilaku ( $\left.\mathrm{Y}_{1}\right)$}

Berdasarkan hasil uji statistik bahwa hasil perhitungan pada penelitian ini menunjukan bahwa variabel motivasi hedonis memiliki nilai thitung sebesar 6.18 dan tingkat signifikan $\alpha=$ $5 \%$ adalah $\mathrm{t}_{\text {tabel }}=1.98$. Karena nilai $\mathrm{t}_{\text {hitung }}$ sebesar $6.18 \geq$ nilai $\mathrm{t}_{\text {tabel }}=1.98$, maka dapat disimpulkan bahwa pengaruh yang terjadi antara variabel motivasi hedonis terhadap niat perilaku signifikan secara statistik pada tingkat signifikansi $5 \%$.

Berdasarkan dengan hasil output dari variabel laten interaksi terhadap variabel motivasi hedonis nilai $\mathrm{t}_{\text {hitung }} 3.92$ lebih besar dari pada batas signifikan level $5 \%$ yaitu $\mathrm{t}_{\text {tabel }} 1.96$. Hal ini menunjukan bahwa Ho ditolak. Dapat disimpulkan, keberadaan usia, jenis kelamin, pengalaman sebagai moderasi memperkuat hubungan antara pengaruh motivasi hedonis terhadap niat perilaku.

\section{6) Interpretasi Nilai Harga $\left(\mathbf{X}_{6}\right)$ terhadap Niat perilaku $\left(\mathbf{Y}_{1}\right)$}

Berdasarkan hasil uji statistik bahwa hasil perhitungan pada penelitian ini menunjukan bahwa variabel nilai harga memiliki nilai $t_{\text {hitung }}$ sebesar 16.59 dan tingkat signifikan $\alpha=5 \%$ adalah $t_{\text {tabel }}=1.98$. Karena nilai $t_{\text {hitung }}$ sebesar $16.59 \geq$ nilai $t_{\text {tabel }}=1.98$, maka dapat disimpulkan bahwa pengaruh yang terjadi antara variabel nilai harga terhadap niat perilaku signifikan secara statistik pada tingkat signifikansi 5\%.

Berdasarkan dengan hasil output dari variabel laten interaksi terhadap variabel nilai Harga nilai $t_{\text {hitung }} 4.60$ lebih besar dari pada batas signifikan level $5 \%$ yaitu $t_{\text {tabel }} 1.96$. Dapat disimpulkan, keberadaan usia, jenis kelamin sebagai moderasi memperkuat hubungan antara pengaruh motivasi hedonis terhadap niat perilaku.

\section{7) Interpretasi kebiasaan (X7) terhadap Niat perilaku $\left(\mathbf{Y}_{1}\right)$}

Berdasarkan hasil uji statistik bahwa hasil perhitungan pada penelitian ini menunjukan bahwa variabel kebiasaan memiliki nilai thitung sebesar 15.94 dan tingkat signifikan $\alpha=5 \%$ adalah $\mathrm{t}_{\text {tabel }}=1.98$. Karena nilai $\mathrm{t}_{\text {hitung }}$ sebesar $15.94 \geq$ nilai $\mathrm{t}_{\text {tabel }}=1.98$, maka dapat disimpulkan bahwa pengaruh yang terjadi antara variabel kebiasaan terhadap niat perilaku signifikan secara statistik pada tingkat signifikansi 5\%.

Berdasarkan dengan hasil output dari variabel laten interaksi terhadap variabel kebiasaan nilai $t_{\text {hitung }} 3.77$ lebih besar dari pada batas signifikan level 5\% yaitu $t_{\text {tabel }} 1.96$. Hal ini menunjukan bahwa Ho ditolak. Dapat disimpulkan, keberadaan usia, jenis kelamin, pengalaman sebagai moderasi memperkuat hubungan antara pengaruh kebiasaan terhadap niat perilaku.

\section{8) Interpretasi Kondisi fasilitas $\left(\mathrm{X}_{4}\right)$ terhadap Perilaku menggunakan $\left(\mathrm{Y}_{2}\right)$}

Berdasarkan hasil uji statistik bahwa hasil perhitungan pada penelitian ini menunjukan bahwa variabel kondisi fasilitas memiliki nilai thitung sebesar 2.22 dan tingkat signifikan $\alpha=$ $5 \%$ adalah $\mathrm{t}_{\text {tabel }}=1.98$. Karena nilai $\mathrm{t}_{\text {hitung }}$ sebesar $2.22 \geq$ nilai $\mathrm{t}_{\text {tabel }}=1.98$, maka dapat disimpulkan bahwa pengaruh yang terjadi antara variabel kondisi fasilitas terhadap perilaku menggunakan signifikan secara statistik pada tingkat signifikansi $5 \%$.

\section{9) Interpretasi Kebiasaan $\left(X_{7}\right)$ terhadap Perilaku menggunakan $\left(Y_{2}\right)$}

Berdasarkan hasil uji statistik bahwa hasil perhitungan pada penelitian ini menunjukan bahwa variabel kebiasaan memiliki nilai $t_{\text {hitung }}$ sebesar 0.12 dan tingkat signifikan $\alpha=5 \%$ adalah $\mathrm{t}_{\text {tabel }}=1.98$. Karena nilai $\mathrm{t}_{\text {hitung }}$ sebesar $0.12 \geq$ nilai $\mathrm{t}_{\text {tabel }}=1.98$, maka dapat 
disimpulkan bahwa pengaruh yang terjadi antara variabel kebiasaan terhadap perilaku menggunakan tidak signifikan secara statistik pada tingkat signifikansi 5\%.

Berdasarkan dengan hasil output dari variabel laten interaksi terhadap variabel motivasi hedonis nilai $t_{\text {hitung }}-0.77$ lebih kecil dari pada batas signifikan level $5 \%$ yaitu $t_{\text {tabel }} 1.96$. Hal ini menunjukan bahwa Ho diterima. Dapat disimpulkan, keberadaan usia, jenis kelamin, pengalaman sebagai moderasi, memperlemah hubungan antara pengaruh kebiasaan terhadap niat perilaku.

\section{0) Interpretasi Niat Perilaku ( $\left.\mathbf{Y}_{1}\right)$ terhadap Perilaku menggunakan $\left(\mathbf{Y}_{2}\right)$}

Berdasarkan hasil uji statistik bahwa hasil perhitungan pada penelitian ini menunjukan bahwa variabel niat perilaku memiliki nilai $\mathrm{t}_{\text {hitung }}$ sebesar 0.25 dan tingkat signifikan $\alpha=5 \%$ adalah $\mathrm{t}_{\text {tabel }}=1.98$. Karena nilai $\mathrm{t}_{\text {hitung }}$ sebesar $0.25 \leq$ nilai $\mathrm{t}_{\text {tabel }}=1.98$, maka dapat disimpulkan bahwa pengaruh yang terjadi antara variabel niat perilaku terhadap perilaku menggunakan tidak signifikan secara statistik pada tingkat signifikansi 5\%.

Berdasarkan dengan hasil output dari variabel laten interaksi terhadap variabel motivasi hedonis nilai $t_{\text {hitung }}-0.37$ lebih kecil dari pada batas signifikan level $5 \%$ yaitu $t_{\text {tabel }} 1.96$. Hal ini menunjukan bahwa Ho diterima. Dapat disimpulkan, keberadaan usia, jenis kelamin, pengalaman sebagai moderasi, memperlemah hubungan antara pengaruh niat perilaku terhadap perilaku menggunakan.

\subsection{Evaluasi Model Struktural}

Uji model struktural untuk melihat seberapa besar tingkat penerimaan yang ada dalam model UTAUT 2. Evaluasi model struktural dengan lisrel- SEM dilihat hasil $R$-square. Berdasarkan hasil olah data menggunakan software lisrel v 8.70 dihasilkan nilai $R$-square dalam Tabel 3 .

Tabel 3 Nilai $R$-square

\begin{tabular}{ll}
\hline \multicolumn{1}{c}{ Variabel } & Nilai $\boldsymbol{R}$-square \\
\hline Niat Perilaku & 0.73 \\
\hline Perilaku Menggunakan & 0.094 \\
\hline
\end{tabular}

(Sumber: Hasil Pengolahan Data)

Berdasarkan Tabel 3, menunjukan bahwa nilai $R$-square variabel niat perilaku 0.73 . dalam hal ini berarti presentase besarnya pengaruh espektasi kinerja, espektasi usaha, pengaruh sosial, kondisi fasilitas, motivasi hedonis, nilai harga, kebiasaan terhadap niat perilaku sebesar $73 \%$ sisa nya $27 \%$ dipengaruhi oleh faktor lain. Kemudian nilai $R$-square variabel perilaku menggunakan sebesar 0.094. Dalam hal ini berarti presentase besarnya pengaruh espektasi kinerja, espektasi usaha, pengaruh sosial, kondisi fasilitas, motivasi hedonis, nilai harga, kebiasaan terhadap perilaku menggunakan sebesar $9.4 \%$ sisa nya $90,6 \%$ dipengaruhi oleh faktor lain.

Menurut prihantara, dkk (2015) untuk melihat berapa besar tingkat penerimaan pada sistem dilihat dari nilai $R$-square variabel endogen perilaku menggunakan sebesar 0.094. Berdasarkan hasil nilai $R$-square artinya besar tingkat penerimaan model UTAUT 2 sebesar $9.4 \%$.

\subsection{Pembahasan}

\section{1) Espektasi Kinerja $\left(\mathbf{X}_{1}\right)$ Terhadap Niat Perilaku ( $\left.\mathbf{Y}_{1}\right)$}

Berdasarkan pengujian hipotesis yang telah dilakukan di dapat bahwa $\mathrm{H}_{\mathrm{o}}$ yang diajukan ditolak. Output t-value menunjukan bahwa nilai thitung untuk variabel espektasi kinerja terhadap niat perilaku diatas $t_{\text {hitung }} 16.46 \geq$ nilai $\mathrm{t}_{\text {tabel }}=1.98$ sehingga pengaruh yang diberikan oleh espktasi kinerja terhadap variabel niat perilaku terbukti signifikan. Dapat disimpulkan bahwa, espektasi kinerja seseorang dalam menggunakan sistem informasi akademik di Akademi Keperawatan Pembina 
Palembang dapat membantu pekerjaan mahasiswa dan dosen serta kebutuhan akan pengguna dalam proses perkuliahan dapat terpenuhi.

\section{2) Pengaruh Espektasi Usaha $\left(\mathbf{X}_{2}\right)$ terhadap Niat Perilaku $\left(\mathbf{Y}_{1}\right)$}

Berdasarkan pengujian hipotesis yang telah dilakukan di dapat bahwa $\mathrm{H}_{\mathrm{o}}$ yang diajukan ditolak. Output t-value menunjukan bahwa nilai thitung untuk variabel espektasi usaha terhadap niat perilaku diatas $t_{\text {hitung }} 16.54 \geq$ nilai $\mathrm{t}_{\text {tabel }}=1.98$ sehingga pengaruh yang diberikan oleh espktasi usaha terhadap variabel niat perilaku terbukti signifikan. Dapat disimpulkan bahwa, espektasi usaha seseorang dalam menggunakan sistem informasi akademik mudah digunakan dan dipahami, sehingga menimbulkan niat perilaku untuk menggunakan sistem informasi akademik dalam mendukung proses perkuliahan.

\section{3) Pengaruh Pengaruh Sosial $\left(\mathrm{X}_{3}\right)$ terhadap Niat Perilaku $\left(\mathbf{Y}_{1}\right)$}

Berdasarkan pengujian hipotesis yang telah dilakukan di dapat bahwa $\mathrm{H}_{\mathrm{o}}$ yang diajukan ditolak. Output t-value menunjukan bahwa nilai $t_{\text {hitung }}$ untuk variabel pengaruh sosial terhadap niat perilaku diatas $t_{\text {hitung }} 14.85 \geq$ nilai $t_{\text {tabel }}=1.98$ sehingga pengaruh yang diberikan oleh pengaruh sosial terhadap variabel niat perilaku terbukti signifikan. Dapat disimpulkan bahwa, pengguna mendapatkan dukungan dari pihak kampus seperti admin sistem informasi akademik di Akademi Keperawatan Pembina Palembang untuk menggunakan sistem informasi akademik tersebut. Dan juga di pengaruhi oleh tututan atas dasar kebutuhan dari dosen dan mahasiswa agar mempercepat proses perkuliahan.

\section{4) Pengaruh Kondisi Fasilitas $\left(\mathbf{X}_{4}\right)$ terhadap Niat Perilaku $\left(\mathbf{Y}_{1}\right)$}

Berdasarkan pengujian hipotesis yang telah dilakukan di dapat bahwa $\mathrm{H}_{\mathrm{o}}$ yang diajukan diterima. Output t-value menunjukan bahwa nilai thitung untuk variabel kondisi fasilitas terhadap niat perilaku diatas $t_{\text {hitung }} 1.65 \leq$ nilai $t_{\text {tabel }}=1.98$ sehingga pengaruh yang diberikan oleh kondisi fasilitas terhadap variabel niat perilaku terbukti tidak signifikan. Dapat disimpulkan bahwa, pengguna merasa pengetahuan yang dibutuhkan untuk menggunakan sistem informasi akademik terasa masih kurang dikarenakan masih sedikitnya sosialisasi mengenai cara penggunaan sistem informasi akademik tentang fitur-fitur yang ada sehingga membuat pengguna kurang paham fungsi fitur-fitur yang ada di sistem informasi akademik tersebut di awal perkuliahan.

\section{5) Pengaruh Motivasi Hedonis ( $\left.\mathbf{X}_{5}\right)$ terhadap Niat Perilaku ( $\left.\mathbf{Y}_{1}\right)$}

Berdasarkan pengujian hipotesis yang telah dilakukan di dapat bahwa $\mathrm{H}_{\mathrm{o}}$ yang diajukan ditolak. Output $t$-value menunjukan bahwa nilai thitung untuk variabel motivasi hedonis terhadap niat perilaku diatas $t_{\text {hitung }} 6.18 \geq$ nilai $t_{\text {tabel }}=1.98$ sehingga pengaruh yang diberikan oleh motivasi hedonis terhadap variabel niat perilaku terbukti signifikan. Dapat disimpulkan bahwa, kesenangan yang diperoleh pengguna dalam menggunakan sistem informasi akademik mempengaruhi niat perilaku karena dapat menyelesaikan proses perkuliahan dengan cepat.

\section{6) Pengaruh Nilai Harga $\left(\mathrm{X}_{6}\right)$ terhadap Niat Perilaku $\left(\mathrm{Y}_{1}\right)$}

Berdasarkan pengujian hipotesis yang telah dilakukan di dapat bahwa $\mathrm{H}_{\mathrm{o}}$ yang diajukan ditolak. Output $t$-value menunjukan bahwa nilai $t_{\text {hitung }}$ untuk variabel nilai harga terhadap niat perilaku diatas $t_{\text {hitung }} 16.59 \geq$ nilai $t_{\text {tabel }}=1.98$ sehingga pengaruh yang diberikan oleh nilai harga terhadap variabel niat perilaku terbukti signifikan. Dapat disimpulkan bahwa, biaya penggunaan internet dalam mengakses sistem informasi akademik cukup terjangau, dimana Akademi Keperawatan Pembina Palembang menyediakan wifi, sehingga pengguna dapat menggunakan tanpa memakai data seluler sendiri.

\section{7) Pengaruh Kebiasaan $\left(X_{7}\right)$ terhadap Niat Perilaku $\left(Y_{1}\right)$}

Berdasarkan pengujian hipotesis yang telah dilakukan di dapat bahwa $\mathrm{H}_{\mathrm{o}}$ yang diajukan ditolak. Output $t$-value menunjukan bahwa nilai $t_{\text {hitung }}$ untuk variabel nilai harga terhadap niat perilaku diatas $t_{\text {hitung }} 15.94 \geq$ nilai tabel $=1.98$ sehingga pengaruh yang diberikan oleh nilai harga terhadap variabel niat perilaku terbukti signifikan. Dapat disimpulkan bahwa, semakin terbiasa pengguna menggunakan sistem informasi akademik, maka dapat menyebabkan meningkatkan niat perilaku untuk menggunakan sistem informasi akademik tersebut. Selain 
itu juga, mahasiswa sebagai pengguna terbiasa dalam menggunakan sistem informasi akademik, karena di setiap semester mahasiswa akan mengambil KRS (Kartu Rencana Studi) yaitu dengan mengakses sistem informasi akademik dalam proses perkuliahan.

\section{8) Pengaruh Kondisi Fasilitas $\left(\mathrm{X}_{4}\right)$ terhadap Perilaku Menggunakan $\left(\mathbf{Y}_{2}\right)$}

Berdasarkan pengujian hipotesis yang telah dilakukan di dapat bahwa $\mathrm{H}_{\mathrm{o}}$ yang diajukan ditolak. Output t-value menunjukan bahwa nilai thitung untuk variabel kondisi fasilitas terhadap perilaku menggunakan diatas $t_{\text {hitung }} 2.22 \geq$ nilai $t_{\text {tabel }}=1.98$ sehingga pengaruh yang diberikan oleh kondisi fasilitas terhadap variabel perilaku menggunakan terbukti signifikan. Dapat disimpulkan bahwa, pengguna sistem informasi akademik sudah mendapatkan fasilitas yang mencukupi dalam menggunakan sistem informasi akademik, seperti wifi yang disediakan oleh Akademi Keperawatan Pembina Palembang yang dapat digunakan untuk menggunakan sistem informasi akademik tersebut.

\section{9) Pengaruh Kebiasaan $\left(\mathbf{X}_{7}\right)$ terhadap Perilaku Menggunakan $\left(\mathbf{Y}_{2}\right)$}

Berdasarkan pengujian hipotesis yang telah dilakukan di dapat bahwa $\mathrm{H}_{\mathrm{o}}$ yang diajukan diterima. Output t-value menunjukan bahwa nilai $t_{\text {hitung }}$ untuk variabel kebiasaan terhadap perilaku menggunakan diatas $t_{\text {hitung }} 0.12 \leq$ nilai $\mathrm{t}_{\text {tabel }}=1.98$ sehingga pengaruh yang diberikan oleh kebiasaan terhadap variabel perilaku menggunakan terbukti tidak signifikan. Dapat disimpulkan bahwa, meskipun pengguna menggunakan sistem informasi akademik terus menerus untuk mengambil KRS tetapi pengguna merasa bahwa tidak menjadi prioritas utama ketika pengguna sudah mengambil KRS dan mengakses sistem informasi akademik tersebut.

\section{0) Pengaruh Niat Perilaku ( $\left.\mathbf{Y}_{1}\right)$ terhadap Perilaku Menggunakan $\left(\mathbf{Y}_{2}\right)$}

Berdasarkan pengujian hipotesis yang telah dilakukan di dapat bahwa $\mathrm{H}_{\mathrm{o}}$ yang diajukan diterima. Output $t$-value menunjukan bahwa nilai $t_{\text {hitung }}$ untuk variabel niat perilaku terhadap perilaku menggunakan diatas $t_{\text {hitung }} 0.25 \geq$ nilai $t_{\text {tabel }}=1.98$ sehingga pengaruh yang diberikan oleh niat perilaku terhadap variabel perilaku menggunakan terbukti tidak signifikan. Dapat disimpulkan bahwa, meskipun menggunakan sistem informasi akademik merupakan kewajiban mahasiswa dan dosen dalam mempermudah proses perkuliahan tetapi, pada kenyataanya bahwa niat perilaku tidak memiliki pengaruh yang signifikan untuk menggunakan sistem informasi akademik karena dosen dan mahasiswa menggunakan sistem informasi akademik hanya formalitas untuk kebutuhan perkuliahan saja.

11) Variabel $(\mathrm{X} 4)$ terhadap $\left(\mathrm{Y}_{1}\right)$ dimoderasi $\left(\mathrm{Z}_{1}\right),\left(\mathrm{Z}_{2}\right),\left(\mathrm{Z}_{3}\right)$

Berdasarkan hasil pengujian hipotesis dari variabel laten interaksi terhadap variabel kondisi fasilitas nilai $t_{\text {hitung }} 5.38$ lebih besar dari pada batas signifikan level 5\% yaitu tabel 1.98. Dapat disimpulkan bahwa pengguna menyadari sudah mendapatkan fasilitas yang memadai untuk menggunakan sistem informasi. Niat perilaku ini juga didukung oleh usia penggunanya, dimana dilihat dari usia responden $<20$ tahun-30 tahun lebih mendukung penggunaan sistem informasi akademik di Akademi Keperawatan Pembina Palembang dikarenakan dilihat dari hasil rekapitulasi responden. Dapat dilihat bahwa kondisi fasilitas terhadap niat perilaku yang dimoderasi sesuai dengan fakta lapangan yang sebagian besar berjenis kelamin perempuan yang memberikan hasil penelitian yang positif terhadap niat perilaku. Niat perilaku juga didukung oleh pengalaman penggunanya, dimana semua pengguna berpengalaman dalam menggunakan sistem informasi akademik tersebut dikarenakan dilihat dari hasil rekapitulasi responden.

\section{2) Variabel $\left(X_{5}\right)$ terhadap $\left(Y_{1}\right)$ dimoderasi $\left(Z_{1}\right),\left(Z_{2}\right),\left(Z_{3}\right)$}

Berdasarkan hasil pengujian hipotesis dari variabel laten interaksi terhadap variabel motivasi hedonis nilai $t_{\text {hitung }} 3.92$ lebih besar dari pada batas signifikan level $5 \%$ yaitu $t_{\text {tabel }}$ 1.96. Dapat disimpulkan bahwa menggunakan sistem informasi akademik memberikan kesenangan terhadap pengguna karena dapat menyelesaikan proses akademik dengan lebih cepat sehingga waktu yang digunakan oleh pengguna di akademi keperawatan pembina lebih efektif dan efisien. Niat perilaku ini juga didukung oleh usia penggunanya, dimana dilihat dari usia responden $<20$ tahun-30 tahun lebih mendukung penggunaan sistem informasi 
akademik di Akademi Keperawatan Pembina Palembang dikarenakan dilihat dari hasil rekapitulasi responden. Niat perilaku ini juga didukung oleh jenis kelamin penggunaanya, dimana jenis kelamin wanita lebih mendukung penggunaan sistem informasi akademik di Akademi Keperawatan Pembina Palembang dikarenakan dilihat dari hasil rekapitulasi responden. Niat perilaku juga didukung oleh pengalaman penggunanya, dimana semua pengguna berpengalaman dalam menggunakan sistem informasi akademik tersebut dikarenakan dilihat dari hasil rekapitulasi responden.

\section{3) Variabel $\left(\mathbf{X}_{6}\right)$ terhadap $\left(\mathbf{Y}_{1}\right)$ dimoderasi $\left(\mathbf{Z}_{1}\right),\left(\mathbf{Z}_{2}\right)$}

Berdasarkan hasil pengujian hipotesis dari variabel laten interaksi terhadap variabel nilai Harga nilai $t_{\text {hitung }} 4.60$ lebih besar dari pada batas signifikan level 5\% yaitu $t_{\text {tabel }} 1.96$. Dapat disimpulkan bahwa biaya yang dikeluarkan oleh pengguna dalam menggunakan sistem informasi akademik memberikan dampak yang positif. Niat perilaku ini juga didukung oleh usia penggunanya, dimana dilihat dari usia responden $<20$ tahun-30 tahun lebih mendukung penggunaan sistem informasi akademik di Akademi Keperawatan Pembina Palembang dikarenakan dilihat dari hasil rekapitulasi responden. Niat perilaku ini juga didukung oleh jenis kelamin penggunaanya, dimana jenis kelamin wanita lebih mendukung penggunaan sistem informasi akademik di Akademi Keperawatan Pembina Palembang dikarenakan dilihat dari hasil rekapitulasi responden. Hasil penelitian ini sesuai fakta dilapangan pengguna dengan sangat mudah mengakses sistem tersebut dengan menggunakan wifi kampus yang telah disediakan sehingga pengguna yang berada dilingkungan kampus bisa mengakses sistem informasi akademik tersebut, sehingga nilai harga terhadap niat perilaku yang dimoderasi umur, jenis kelamin menghasilkan hasil yang positif.

\section{4) Kebiasaan $\left(X_{7}\right)$ terhadap $\left(Y_{1}\right)$ dimoderasi $\left(Z_{1}\right),\left(Z_{2}\right),\left(Z_{3}\right)$}

Berdasarkan hasil pengujian hipotesis dari variabel laten interaksi terhadap variabel kebiasaan nilai thitung 3.77 lebih besar dari pada batas signifikan level 5\% yaitu tabel 1.96 . Dapat disimpulkan bahwa semua mahasiswa aktif dan dosen terbiasa mengggunakan sistem informasi akademik dalam proses akademik di Akademi Keperawatan Pembina Palembang. Niat perilaku ini juga didukung oleh usia penggunanya, dimana dilihat dari usia responden < 20 tahun-30 tahun lebih mendukung penggunaan sistem informasi akademik di Akademi Keperawatan Pembina Palembang dikarenakan dilihat dari hasil rekapitulasi responden. Niat perilaku ini juga didukung oleh jenis kelamin penggunaanya, dimana jenis kelamin wanita lebih mendukung penggunaan sistem informasi akademik di Akademi Keperawatan Pembina Palembang dikarenakan dilihat dari hasil rekapitulasi responden. Niat perilaku juga didukung oleh pengalaman penggunanya, dimana semua pengguna berpengalaman dalam menggunakan sistem informasi akademik tersebut dikarenakan dilihat dari hasil rekapitulasi responden.

\section{5) Variabel $\left(\mathrm{X}_{7}\right)$ terhadap $\left(\mathrm{Y}_{2}\right)$ dimoderasi $\left(\mathrm{Z}_{1}\right),\left(\mathbf{Z}_{2}\right),\left(\mathbf{Z}_{3}\right)$}

Berdasarkan hasil pengujian hipotesis dari variabel laten interaksi terhadap variabel motivasi hedonis nilai $t_{\text {hitung }}-0.77$ lebih kecil dari pada batas signifikan level $5 \%$ yaitu $t_{\text {tabel }}$ 1.96. Dapat disimpulkan bahwa kebiasaan akan berdampak pada penggunaan sistem informasi akademik, karena dengan kebiasaan berinteraksi dalam penggunaan sistem informasi akademik maka akan semakin bisa untuk menggunakannya dengan frekuensi penggunaan yang tinggi makan perilaku menggunakan untuk menggunakan sistem informasi akademik tidak terlalu signifikan. Perilaku menggunakan ini juga didukung oleh usia penggunanya, dimana usia $<20$ tahun -30 tahun lebih mendukung penggunaan sistem informasi akademik di Akademi Keperawatan Pembina Palembang dilihat dari hasil rekapitulasi responden. Meskipun perilaku penggunaan untuk menggunakan sistem informasi akademik tidak terlalu signifikan. Perilaku menggunakan ini juga didukung oleh jenis kelamin penggunaanya, dimana jenis kelamin wanita lebih mendukung penggunaan sistem informasi akademik di Akademi Keperawatan Pembina Palembang dilihat dari hasil rekapitulasi responden. Perilaku menggunakan juga didukung oleh pengalaman 
penggunanya, dimana semua pengguna berpengalaman dalam menggunakan sistem informasi akademik tersebut dilihat dari hasil rekapitulasi responden.

\section{6) Variabel $\left(Y_{1}\right)$ terhadap $\left(Y_{2}\right)$ dimoderasi $\left(Z_{3}\right)$}

Berdasarkan hasil pengujian hipotesis dari variabel laten interaksi terhadap variabel motivasi hedonis nilai $t_{\text {hitung }}-0.37$ lebih kecil dari pada batas signifikan level $5 \%$ yaitu $t_{\text {tabel }}$ 1.96. Dapat disimpulkan bahwa mahasiswa dan dosen memiliki niat yang tinggi untuk menggunakan sistem informasi akademik dalam proses perkuliahan, karena dengan sistem informasi akademik dapat mempermudah proses akademik. Perilaku menggunakan ini juga didukung oleh pengalaman penggunanya, semua pengguna berpengalaman dalam menggunakan sistem informasi akademik tersebut, meskipun perilaku pengguna untuk menggunakan sistem informasi akademik tidak terlalu signifikan.

\section{KESIMPULAN}

Berdasarkan hasil penelitian yang telah dilakukan dapat diambil simpulan yaitu:

1) Berdasarkan model UTAUT 2, bahwa faktor-faktor yang berpengaruh terhadap niat perilaku penerimaan sistem informasi akademik yaitu, variabel espektasi kinerja berpengaruh sebesar 16.46, variabel espektasi usaha berpengaruh sebesar 16.54, variabel pengaruh social berpengaruh sebesar 14.85, variabel motivasi hedonis berpengaruh sebesar 6.18, variabel nilai harga berpengaruh sebesar 16.59, variabel kebiasaan berpengaruh sebesar 15.94. Kemudian variabel kondisi fasilitas terhadap perilaku menggunakan berpengaruh sebesar 2.22.

2) Untuk melihat seberapa besar penerimaan sistem informasi akademik dengan menggunakan model UTAUT 2, maka sesuai dengan analisis data metode SEM dilihat dari nilai koefisien determinasi variabel endogen variabel perilaku menggunakan sebesar $9.4 \%$.

\section{DAFTAR RUJUKAN}

Budiarto, Raden. 2018. Analisis Faktor Adopsi Aplikasi Mobile Berdasarkan Pengalaman, Usia dan Jenis Kelamin Menggunakan UTAUT2. Jurnal Ilmiah Teknologi Sistem Informasi 3(2). ISSN: 2502-3357.114-126.

Gayatrie, Mega Shero., Ari Kusyanti, dan Mochammad Chandra Saputra. 2017. Analisis

Penerimaan Os Windows 10 Dengan Unified Theory of Acceptance and Use of

Technology (UTAUT 2). Jurnal Pengembangan Teknologi Informasi dan Ilmu Komputer 1(6). ISSN: 2548-964X.514-523.

Putra, Gioliano dan Maya Ariyanti. 2013. Pengaruh Faktor-faktor Dalam Modified Unified Theory of Acceptance and Use of Technology 2 (UTAUT 2) Terhadap Niat Prospective Users untuk Mengadopsi Home Digital Services PT. Telkom di Surabaya. Jurnal Manajemen Indonesia 12 (4).

Tentama, Fatwa., Subardjo. 2016. Pengujian Validitas dan Reliabilitas Konstruk pada

Organizational Citizenship Behavior. Fakultas Psikologi, Universitas Ahmad Dahlan Yogyakarta 15(1). ISSN: 1693-7236. 
Venkatesh, Viswanath., Michael G. Morris., Gordon B. Davis, dan Fred D. Davis. 2003. User Acceptance of Information Technology: Toward a Unfied View. MIS Quarterly 27(3).

Venkatesh, Viswanath., James Y.L. Thong, dan Xin Xu. 2012. Costumer Acceptance and Use of Information Technology: Extending The Unified Theory of Acceptance and Use of Technology. MIS Quarterly 36(1).

Widiyasari, Ririn, Mutiarani 2017. Penggunaan Metode Structural Equation Modelling untuk Analisis faktor - faktor yang mempengaruhi Motivasi Belajar Mahasiswa FIP UMJ. Jurnal Pendidikan Matematika dan Matematika 3(2). ISSN: 2460 - 7797 